\title{
Assessment of Undiscovered Conventional Oil Resources of the East Gobi, Nyalga, Tamtsag-Hailar, Erlian, and Yingen Basins of Mongolia and China, 2018
}

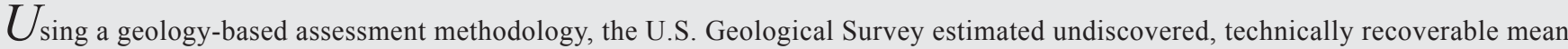
conventional resources of 187 million barrels of oil and 85 billion cubic feet of gas in the East Gobi, Nyalga, Tamtsag-Hailar, Erlian, and Yingen basins of Mongolia and China.

\section{Introduction}

The U.S. Geological Survey (USGS) quantitatively assessed the potential for undiscovered, technically recoverable conventional oil resources in the East Gobi, Nyalga, Tamtsag-Hailar, Erlian, and Yingen basins of Mongolia and China (fig. 1). These basins, which represent groups of subbasins, share a similar tectonic history and development of petroleum systems (Meng, 2003; Meng and others, 2003; Windley and others, 2007; Wilhem and others, 2012). Middle Jurassic and Late Jurassic-Early Cretaceous extension formed a regional system of extensional basins that was filled with synrift nonmarine facies, including alluvial, fluvial, deltaic; marginal lacustrine sandstones; and shallow-to-deep-water lacustrine shales (Changsong and others, 2001). In these five basins, petroleum source rocks are organic-rich, deep-water lacustrine shales (Traynor and Sladen, 1995; Graham and others, 2001; Johnson and others, 2003; Johnson, 2004; Prost, 2004; Ding and others, 2015 Luo and others, 2018). Following cessation of rifting, a thermal sag phase led to increased accommodation space and deposition, resulting in local source-rock maturation and petroleum migration. However, the sag phase of deposition was interrupted by regional compression, uplift, and erosion in the Late Cretaceous that inverted many of the extensional structures, largely curtailed the thermal maturation process, and may have caused remigration of oil or loss of oil from conventional traps.

\section{Total Petroleum System and Assessment Units}

The Mesozoic Composite Total Petroleum System was defined to encompass petroleum generated from synrift, Lower Cretaceous lacustrine source rocks and from lacustrine shales such as in the Middle Jurassic Eedemt Formation (Hasegawa and others, 2018). Although geochemical parameters for source rocks are variable across the basins, the lacustrine source rocks contain Type I kerogen (with minor Type III kerogen), are as much as $700 \mathrm{~m}$ thick, are as much as 10 weight percent total organic carbon, and have hydrogen index values that are as much as 600 milligrams of hydrocarbon per gram organic carbon. In each basin, an assessment unit was defined to include all potential undiscovered conventional oil accumulations sourced by these lacustrine rocks.

The geologic model is that oil was generated from synrift lacustrine source rocks in those subbasins that have reached the thermal maturity window for oil generation. Once generated, this oil may have migrated into synrift reservoirs and may have been trapped only to possibly remigrate during Late Cretaceous inversion. Remigration may have resulted in the loss of oil from conventional traps. The range of uncertainty on the assessment input (table 1) reflects the level of uncertainty on the extent of source-rock facies within the grabens, the level of thermal maturation of lacustrine source rock, and the retention of oil within traps following compression and inversion. Assessment input data are summarized in table 1.

\section{Undiscovered Resources Summary}

The USGS quantitatively assessed conventional oil and associated gas resources in five assessment units (table 2) in the East Gobi, Nyalga, Tamtsag-Hailar, Erlian, and Yingen basins of Mongolia and China. For undiscovered, technically recoverable resources, the mean totals are 187 million barrels of oil (MMBO) with an F95-F5 fractile range from 0 to $453 \mathrm{MMBO}$ and 85 billion cubic feet of associated gas (BCFG) with an F95-F5 fractile range of 0 to 212 BCFG. Of the mean total of $187 \mathrm{MMBO}$, about 86 percent, or $162 \mathrm{MMBO}$, is estimated to be in the Tamtsag-Hailar basin (100 MMBO) and Erlian basin (62 MMBO).

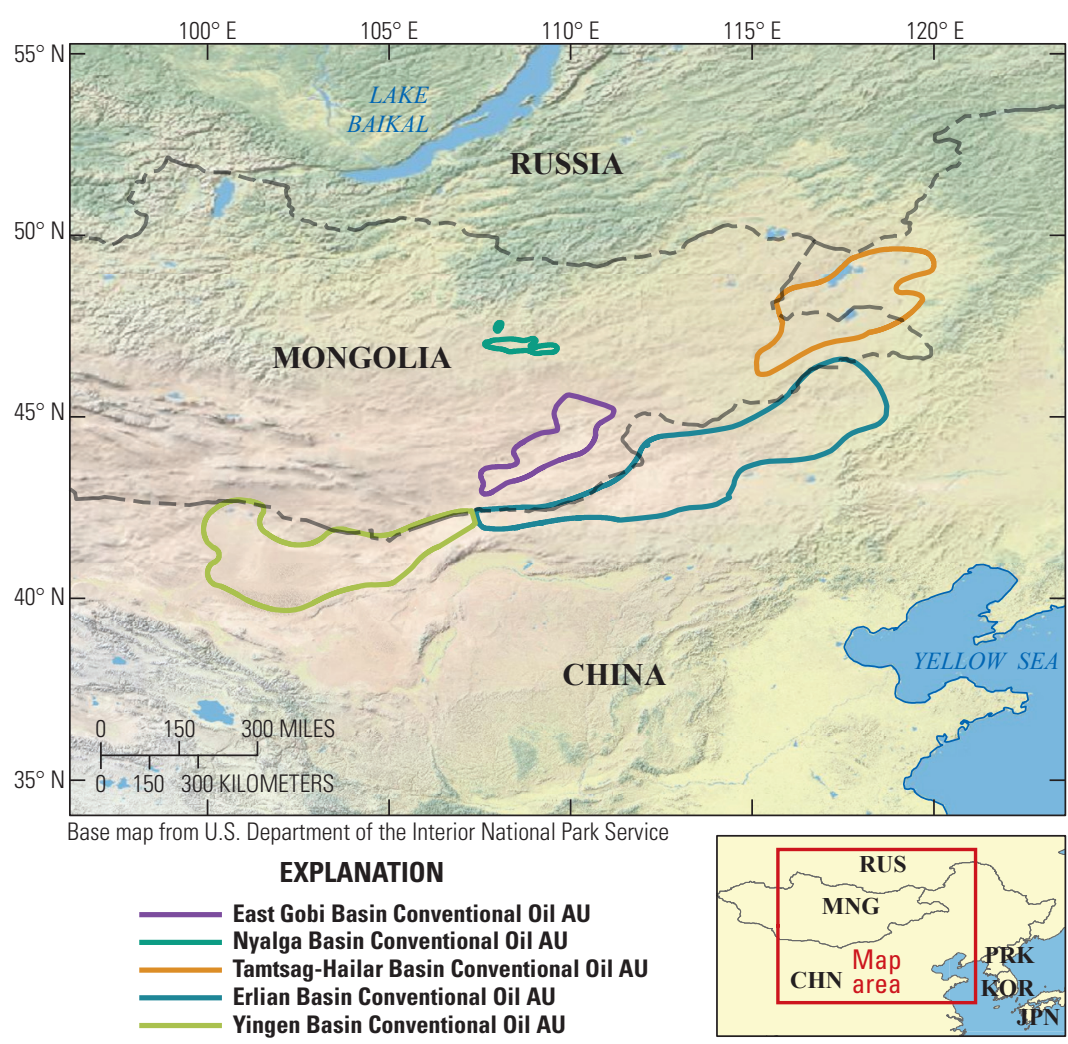

Figure 1. Map showing five conventional assessment units (AUs) in the East Gobi, Nyalga, Tamtsag-Hailar, Erlian, and Yingen basins of Mongolia and China. 
Table 1. Key input data for five conventional assessment units (AUs) in the East Gobi, Nyalga, Tamtsag-Hailar, Erlian, and Yingen basins of Mongolia and China.

[AU, assessment unit; MMBO, million barrels of oil. Shading indicates not applicable]

\begin{tabular}{|c|c|c|c|c|c|c|c|c|}
\hline \multirow{2}{*}{$\begin{array}{l}\text { Assessment input data- } \\
\text { Conventional AUs }\end{array}$} & \multicolumn{4}{|c|}{ East Gobi Basin Conventional Oil AU } & \multicolumn{4}{|c|}{ Nyalga Basin Conventional Oil AU } \\
\hline & Minimum & Median & Maximum & Calculated mean & Minimum & Median & Maximum & Calculated mean \\
\hline Number of oil fields & 1 & 5 & 15 & 5.3 & 1 & 5 & 20 & 5.5 \\
\hline Size of oil fields (MMBO) & 0.5 & 1 & 40 & 1.8 & 0.5 & 1 & 40 & 1.8 \\
\hline AU probability & 0.8 & & & & 0.8 & & & \\
\hline \multirow{2}{*}{$\begin{array}{c}\text { Assessment input data- } \\
\text { Conventional AUs }\end{array}$} & \multicolumn{4}{|c|}{ Tamtsag-Hailar Basin Conventional Oil AU } & \multicolumn{4}{|c|}{ Erlian Basin Conventional Oil AU } \\
\hline & Minimum & Median & Maximum & Calculated mean & Minimum & Median & Maximum & Calculated mean \\
\hline Number of oil fields & 1 & 20 & 40 & 20.5 & 1 & 20 & 40 & 20.5 \\
\hline Size of oil fields (MMBO) & 0.5 & 1.5 & 300 & 5.4 & 0.5 & 1.5 & 100 & 3.4 \\
\hline AU probability & 0.9 & & & & 0.9 & & & \\
\hline \multirow{2}{*}{$\begin{array}{c}\text { Assessment input data- } \\
\text { Conventional AUs }\end{array}$} & \multicolumn{4}{|c|}{ Yingen Basin Conventional Oil AU } & & & & \\
\hline & Minimum & Median & Maximum & Calculated mean & & & & \\
\hline Number of oil fields & 1 & 5 & 15 & 5.3 & & & & \\
\hline Size of oil fields (MMBO) & 0.5 & 1 & 100 & 2.5 & & & & \\
\hline AU probability & 0.7 & & & & & & & \\
\hline
\end{tabular}

Table 2. Results for five conventional assessment units (AUs) in the East Gobi, Nyalga, Tamtsag-Hailar, Erlian, and Yingen basins of Mongolia and China.

[MMBO, million barrels of oil; BCFG, billion cubic feet of gas; NGL, natural gas liquids; MMBNGL, million barrels of natural gas liquids. Results shown are fully risked estimates. F95 represents a 95-percent chance of at least the amount tabulated; other fractiles are defined similarly. Fractiles are additive under the assumption of perfect positive correlation. Shading indicates not applicable]

\begin{tabular}{|c|c|c|c|c|c|c|c|c|c|c|c|c|c|c|}
\hline \multirow{3}{*}{$\begin{array}{l}\text { Total petroleum system } \\
\text { and assessment units (AUs) }\end{array}$} & \multirow{3}{*}{$\begin{array}{c}\text { AU } \\
\text { probability }\end{array}$} & \multirow{3}{*}{$\begin{array}{c}\text { Accumulation } \\
\text { type }\end{array}$} & \multicolumn{12}{|c|}{ Total undiscovered resources } \\
\hline & & & \multicolumn{4}{|c|}{ Oil (MMBO) } & \multicolumn{4}{|c|}{ Gas (BCFG) } & \multicolumn{4}{|c|}{ NGL (MMBNGL) } \\
\hline & & & F95 & F50 & F5 & Mean & F95 & F50 & F5 & Mean & F95 & F50 & F5 & Mean \\
\hline \multicolumn{15}{|c|}{ Mesozoic Composite Total Petroleum System } \\
\hline East Gobi Basin Conventional Oil AU & 0.8 & Oil & 0 & 6 & 21 & 8 & 0 & 3 & 9 & 3 & 0 & 0 & 0 & 0 \\
\hline Nyalga Basin Conventional Oil AU & 0.8 & Oil & 0 & 6 & 23 & 8 & 0 & 2 & 9 & 3 & 0 & 0 & 0 & 0 \\
\hline Tamtsag-Hailar Basin Conventional Oil AU & 0.9 & Oil & 0 & 84 & 249 & 100 & 0 & 41 & 127 & 50 & 0 & 0 & 0 & 0 \\
\hline Erlian Basin Conventional Oil AU & 0.9 & Oil & 0 & 59 & 128 & 62 & 0 & 23 & 54 & 25 & 0 & 0 & 0 & 0 \\
\hline Yingen Basin Conventional Oil AU & 0.7 & Oil & 0 & 6 & 32 & 9 & 0 & 2 & 13 & 4 & 0 & 0 & 0 & 0 \\
\hline Total undiscovered conventional resources & & & 0 & 161 & 453 & 187 & 0 & 71 & 212 & 85 & 0 & 0 & 0 & 0 \\
\hline
\end{tabular}

\section{References Cited}

Changsong, L., Eriksson, K., Sitian, L., Yongxian, W., Jianye, R., and Yanmei, Z., 2001, Sequence architecture, depositional systems, and controls on development of lacustrine basin fills in part of the Erlian basin, northeast China: American Association of Petroleum Geologists Bulletin, v. 85, no. 11, p. 2017-2043.

Ding, X., Liu, G., Zha, M., Huang, Z., Gao, C., Wang, P., Qu, J., Lu, X., and Chen, Z., 2015, Characteristics and origin of lacustrine source rocks in the Lower Cretaceous, Erlian Basin, northern China: Marine and Petroleum Geology, v. 66, pt. 4, p. 939-955.

Graham, S.A., Hendrix, M.S., Johnson, C.L., Badamgarav, D., Badarch, G., Amory, J., Porter, M., Barsbold, R., Webb, L.E., and Hacker, B.R., 2001, Sedimentary record and tectonic implications of Mesozoic rifting in southeast Mongolia: Geological Society of America Bulletin, v. 113, no. 12, p. 1560-1579.

Hasegawa, H., Ando, H., Hasebe, N., Ichinnorov, N., Ohta, T., Hasegawa, T., Yamamoto, M., Li, G., Erdenetsogt, B.-O., Heimhofer, U., Murata, T., Shinya, H., Enerel, G., Oyunjargal, G., Munkhtsetseg, O., Suzuki, N., Irino, T., and Yamamoto, K., 2018, Depositional ages and characteristics of Middle-Upper Jurassic and Lower Cretaceous lacustrine deposits in southeastern Mongolia: Island Arc, v. 27, no. 3, p. 1-17.

Johnson, C.L., 2004, Polyphase evolution of the East Gobi basin-Sedimentary and structural records of Mesozoic-Cenozoic intraplate deformation in Mongolia: Basin Research, v. 16, no. 1, p. 79-99.
Johnson, C.L., Greene, T.J., Zinniker, D.A., Moldowan, J.M., Hendrix, M.S., and Carroll, A.R., 2003, Geochemical characteristics and correlation of oil and nonmarine source rocks from Mongolia: American Association of Petroleum Geologists Bulletin, v. 87, no. 5, p. 817-846.

Luo, Q., Zhong, N., Liu, Y., Qu, Y., and Ma, L., 2018, Organic geochemical characteristics and accumulation of the organic matter in the Jurassic to Cretaceous sediments of the Saihantala Sag, Erlian Basin, China: Marine and Petroleum Geology, v. 92, p. 855-867.

Meng, Q.-R., 2003, What drove late Mesozoic extension of the northern China-Mongolia tract?: Tectonophysics, v. 369, nos. 3-4, p. 155-174.

Meng, Q.-R., Hu, J.-M., Jin, J.-Q, Zhang, Y., and Xu, D.-F., 2003, Tectonics of the late Mesozoic wide extensional basin system in the China-Mongolia border region: Basin Research, v. 15 , no. 3, p. 397-415.

Prost, G.L., 2004, Tectonics and hydrocarbon systems of the East Gobi basin, Mongolia: American Association of Petroleum Geologists Bulletin, v. 88, no. 4, p. 483-513.

Traynor, J.J., and Sladen, C., 1995, Tectonic and stratigraphic evolution of the Mongolian People's Republic and its influence on hydrocarbon geology and potential: Marine and Petroleum Geology, v. 12, no. 1, p. 35-52.

Wilhem, C., Windley, B.F., and Stampfli, G.M., 2012, The Altaids of central Asia-A tectonic and evolutionary innovative review: Earth Science Reviews, v. 113, nos. 3-4, p. 303-341.

Windley, B.F., Alexeiev, D., Xiao, W., Kröner, A., and Badarch, G., 2007, Tectonic models for accretion of the Central Asian Orogenic Belt: London, United Kingdom, Journal of the Geological Society, v. 164, no. 1, p. 31-47.

\section{Mongolia and China Basins Assessment Team}

Christopher J. Schenk, Tracey J. Mercier, Janet K. Pitman, Thomas M. Finn, Cheryl A. Woodall, Kristen R. Marra, Phuong A. Le, and Heidi M. Leathers-Miller

\section{For More Information}

Assessment results are also available at the USGS Energy Resources Program website at https://energy.usgs.gov. 